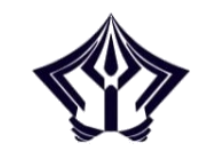

ANFUSINA: JOURNAL OF PSYCHOLOGY

http://ejournal.radenintan.ac.id/index.php/anfusina

DOI: //dx.doi.org/ 10.24042/ajp.v2i2.6097

Volume 2, Nomor 2, Oktober Tahun 2019

\title{
Hubungan Dukungan Keluarga Dengan Kepatuhan Pasien Kanker Payudara Menjalani Kemoterapi Di Rsud Dr. H. Abdul Moeloek
}

\author{
Ghina Efrilia Roza \\ Universitas Malahayati Lampung \\ ghinaefriliaroza@gmail.com \\ Octa Reni Setiawati \\ Universitas Malahayati Lampung \\ ores.survive@gmail.com
}

\begin{abstract}
Breast cancer is the most common type of cancer experienced by women in the world and is also the type of cancer that is the leading cause of death in women. One type of treatment that can be used in the treatment of breast cancer is chemotherapy. Chemotherapy is a type of treatment to kill or slow down the growth of cancer cells which requires a long period of time, where in this treatment required compliance. Adherence in chemotherapy can be influenced by several factors, one of which is family support. To find out the relationship between family support and breast cancer patient's compliance undergoing chemotherapy at RSUD Dr. H. Abdul Moeloek Lampung Province. Analytical observational research with a retrospective approach. The sampling technique is done by accidental sampling. Obtained data from 120 samples that filled out family support questionnaires and medical records of patients undergoing chemotherapy at RSUD Dr. H. Abdul Moeloek, Lampung Province, which has good family support of 101 people (84.2\%) and 108 patients (90.0\%) are obedient to chemotherapy. Kendall-tau test results obtained a significance value of 0.000 which indicates that there is a significant relationship between family support and breast cancer patients adherence undergoing chemotherapy. There is a significant relationship between family support
\end{abstract}


and breast cancer patient compliance undergoing chemotherapy with a correlation coefficient of 0.607 and a significance value of 0.000 .

\begin{abstract}
Abstrak
Kanker payudara merupakan jenis kanker yang paling umum dialami wanita di dunia dan juga merupakan jenis kanker yang menjadi penyebab kematian terbanyak pada wanita. Salah satu jenis pengobatan yang dapat dipakai dalam pengobatan kanker payudara adalah kemoterapi. Kemoterapi adalah jenis pengobatan untuk membunuh atau memperlambat pertumbuhan sel kanker yang membutuhkan jangka waktu lama, dimana dalam pengobatan ini dibutuhkan kepatuhan. Kepatuhan dalam kemoterapi dapat dipengaruhi beberapa faktor salah satunya yaitu dukungan keluarga. Untuk mengetahui hubungan dukungan keluarga dengan kepatuhan pasien kanker payudara menjalani kemoterapi di RSUD Dr. H. Abdul Moeloek Provinsi Lampung. Penelitian observasi analitik dengan pendekatan retrospektif. Teknik pengambilan sampel dilakukan dengan accidental sampling. Didapatkan data dari 120 sampel yang mengisi kuesioner dukungan keluarga dan rekam medik pasien yang menjalani kemoterapi di RSUD Dr. H. Abdul Moeloek Provinsi Lampung yaitu memiliki dukungan keluarga baik sebanyak 101 orang $(84.2 \%)$ dan didapatkan pasien yang patuh terhadap kemoterapi sebanyak 108 orang (90.0\%). Hasil uji kendalltau didapatkan nilai signifikasi sebesar 0.000 yang menunjukkan bahwa terdapat hubungan yang signifikan antara dukungan keluarga dengan kepatuhan pasien kanker payudara menjalani kemoterapi. Terdapat hubungan yang bermakna antara dukungan keluarga dengan kepatuhan pasien kanker payudara menjalani kemoterapi dengan nilai koefisien korelasi 0.607 dan nilai signifikansi 0.000 .
\end{abstract}

Keyword: Family Support, Compliance, Breast Cancer, Chemotherapy

\title{
Pendahuluan
}

Kanker payudara merupakan keganasan pada jaringan payudara yang dapat berasal dari epitel duktus maupun lobulusnya (RI K,2015). Gejala kanker payudara meliputi adanya benjolan di payudara, perubahan bentuk payudara, adanya kerutan di kulit sekitar payudara, keluarnya discharge dari puting susu dan timbulnya kemerahan pada kulit (Brody dkk., 2007).

Kanker payudara merupakan jenis kanker yang paling umum dialami wanita di dunia dan juga merupakan jenis kanker yang menjadi penyebab kematian terbanyak pada wanita di dunia dan juga merupakan jenis kanker yang menjadi penyebab kematian terbanyak pada wanita (Lee dkk., 2014). Pada tahun 2018 didapatkan insidensi kanker payudara di dunia sebanyak 2.088.849 kasus (Bray., 2018). Di 
Provinsi Lampung prevalensi kanker payudara sebanyak 1.148 (Kemenkes RI, 2013).

Kemoterapi adalah jenis pengobatan untuk membunuh atau memperlambat pertumbuhan sel kanker, aakan tetapi, jenis pengobatan ini dapat menimbulkan efek samping. Efek samping yang paling umum adalah pasien mengalami kelemahan, merasa lesu, kerontokkan rambut, dan mual muntah. Selain itu, efek samping yang ditimbulkan dapat berupa diare, nyeri abdomen, mulut kering, bahkan kehilangan memori (Aslam dkk., 2014).

Hasil penelitian yang dilakukan di Rumah Sakit Kanker Dharmais Jakarta menunjukkan kurang dari separuh pasien mengalami gangguan emosional terkait penyakitnya, antara lain emosi yang kurang terkendali, gangguan mood, cemas dan depresi (Ayurini, 2015). Di RSUD Dr. H. Abdul Moeloek didapatkan data sebanyak 166 pasien kanker payudara yang menjalani kemoterapi pada bulan November tahun 2018.

Kepatuhan pasien sangat dibutuhkan dalam pengobatan, baik itu pengobatan jangka pendek maupun pengobatan jangka panjang. Pengobatan jangka panjang lebih rentan terhadap masalah kepatuhan pasien, seringkali pasien merasa jenuh untuk melakukan pengobatan terus menerus dan kemudian tidak patuh dalam pengobatan. Masalah tersebut dapat membawa banyaak dampak bagi pasien seperti memperlambat proses penyembuhan, memperburuk keadaan pasien dan kematian (Ayurini, 2015).

Banyak faktor yang mempengaruhi kepatuhan pasien menjalani kemoterapi. Seperti masalah biaya, tidak tahan terhadap efek samping dan juga proses kemoterapi membutuhkan waktu yang lama, takut akan kematian, serta tidak adanya dukungan keluarga seringkali membuat pasien frustrasi dan akhirnya berhenti berobat (Ayurini, 2015).

Keluarga dapat menjadi faktor yang sangat berpengaruh dalam menentukan keyakinan dan nilai kesehatan individu serta dapat juga menentukan tentang program pengobatan yang dapat mereka terima. Secara umum pasien yang mendapat perhatian dari seseorang atau kelompok biasanya cenderung lebih mudah mengikuti saran medis daripada pasien yang kurang mendapat dukungan sosial.

Bagi pasien kanker yang menjalani kemoterapi, dukungan keluarga sangat penting untuk memotivasi mereka agar terus tetap semangat melaksanakan kemoterapi (Wahyuni dkk., 2016). Oleh karena itu, dukungan keluarga juga dapat mempengaruhi kepatuhan pasien dalam mrnjalani kemoterapi. Maka dari itu peneliti ingin 
mengetahui apakah ada hubungan antara dukungan keluarga dengan kepatuhan pasien kanker payudara menjalani kemoterapi.

\section{Metode Penelitian}

Jenis penelitian ini merupakan penelitian observasi analitik dengan pendekatan waktu yang dipakai dalam penelitian ini adalah Retrospektif yaitu penelitian yang berusaha melihat ke belakang (backward looking), artinya pengumpulan data dimulai dari efek atau akibat yang telah terjadi (Notoatmodjo, 2010). Penelitian ini dilakukan di Ruang Kemoterapi RSUD DR. H Abdul Moeloek pada bulan Januari - Februari tahun 2019.

Populasi pada penelitian ini yaitu seluruh pasien kanker payudara yang menjalani kemoterapi di RSUD DR. H Abdoel Moeloek. Didapatkan jumlah populasi pasien kanker payudara pada bulan November 2018 di RSUD DR H Abdul Moeloek sebanyak 166 pasien dan didapatkan jumlah sampel sebesar 120 pasien. Teknik sampling yang digunakan pada penelitian ini yaitu accidental sampling dimana pengambilan sampel dilakukan dengan mengambil responden yang kebetulan ada atau tersedia (Notoatmodjo, 2010). Alat ukur yang digunakan dalam penelitian ini adalah kuesioner untuk variabel dukungan keluarga dan lembar ceklist kepatuhan untuk variabel kepatuhan.

\section{Hasil dan Pembahasan}

Responden dalam penelitian ini adalah pasien kanker payudara yang sedang menjalani kemoterapi di RSUD Dr. H. Abdul Moeloek Provinisi Lampung. Jumlah sampel dalam penelitian ini yaitu sebanyak 120 sampel yang telah ditentukan dengan menggunakan rumus slovin dan sudah disesuaikan dengan kriteria yang telah ditentukan. Adapun karakteristik responden adalah sebagai berikut.

Tabel 1. Karakteristik Responden

\begin{tabular}{ccc}
\hline Karakteristik & \multicolumn{2}{c}{ Responden } \\
\cline { 2 - 3 } & Frekuensi & Persentase \\
\hline Jenis Kelamin & 120 & $100 \%$ \\
Perempuan & 0 & $0 \%$ \\
Laki-laki & & \\
\hline Usia & 26 & $21,7 \%$ \\
$\leq 40$ Tahun & 94 & $78,3 \%$ \\
$>40$ Tahun & & \\
\hline
\end{tabular}




\begin{tabular}{lcl}
\hline Pendidikan & 3 & \\
Tidak Sekolah & $32,5 \%$ \\
SD & 42 & $35 \%$ \\
SMP & 22 & $18,3 \%$ \\
SMA & 34 & $28,3 \%$ \\
PT & 19 & $15,8 \%$ \\
\hline Pekerjaan & \\
Tidak Bekerja & 84 & $70 \%$ \\
$\quad$ Bekerja & 36 & $30 \%$ \\
\hline Jenis Kombinasi Terapi & & \\
CAF & 98 & $81,7 \%$ \\
Cisplatin \& Paclitaxel & 19 & $15,8 \%$ \\
Bonavel dan Zometa & 1 & $0,8 \%$ \\
Herzemab & 1 & $0,8 \%$ \\
Bandronat & 1 & $0,8 \%$ \\
\hline Jumlah & $\mathbf{1 2 0}$ & $\mathbf{1 0 0} \%$ \\
\hline
\end{tabular}

Berdasarkan tabel 1. didapatkan semua responden berjenis kelamin perempuan yaitu sebanyak 120 orang (100\%). Sebagian besar responden berusia $>40$ tahun yaitu sebanyak 94 orang $(78.3 \%)$. Sebanyak 42 orang (35\%) berpendidikan SD. Sebagian besar responden tidak bekerja yaitu sebanyak 84 orang (70\%). Dan sebagian besar menggunakan jenis kombinasi terapi CAF yaitu sebanyak 98 orang $(81.7 \%)$.

\section{Analisa Univariat}

Analisa ini dilakukan untuk mengetahui distribusi frekuensi dan persentase dari variabel dukungan keluarga dan kepatuhan pada pasien kanker payudara yang menjalani kemoterapi di RSUD Dr. H. Abdul Moeloek pada bulan Januari - Februari tahun 2019.

Tabel 2. Analisa Univariat

\begin{tabular}{lcc}
\hline \multirow{2}{*}{ Variabel } & \multicolumn{2}{c}{ Responden } \\
\cline { 2 - 3 } & Frekuensi & Presentase \\
\hline Dukungan Keluarga & & $84.2 \%$ \\
Baik & 101 & $10 \%$ \\
Cukup & 12 & $5.8 \%$ \\
Kurang & 7 & $90 \%$ \\
Kepatuhan & 108 & $10 \%$ \\
Patuh & 12 & $100 \%$ \\
Tidak Patuh & 120 & \\
\hline Total & &
\end{tabular}


Berdasarkan tabel 2. diatas didapatkan pasien yang memiliki dukungan keluarga baik sebanyak 101 orang (84.2\%), dukungan keluarga cukup sebanyak 12 orang (10.0\%), dukungan keluarga kurang sebanyak 7 orang $(5.8 \%)$. Pasien yang patuh terhadap kemoterapi sebanyak 108 orang $(90.0 \%)$, sedangkan yang tidak patuh terhadap kemoterapi sebanyak 12 orang $(10.0 \%)$.

\section{Analisa Bivariat}

Analisa ini dilakukan untuk mengetahui tingkat ketepatan hubungan variabel independen dengan variabel dependen yang diteliti, yaitu hubungan dukungan keluarga dengan kepatuhan sehingga diketahui kemaknaannya dengan menggunakan uji kendall-tau.

Tabel 3. Tabulasi Silang Dukungan Keluarga terhadap Kepatuhan Pasien Kanker Payudara Menjalani Kemoterapi di RSUD Dr. H. Abdul Moeloek Januari - Februari 2019

\begin{tabular}{|c|c|c|c|c|c|c|}
\hline \multirow{3}{*}{$\begin{array}{l}\text { Dukungan } \\
\text { Keluarga }\end{array}$} & \multicolumn{4}{|c|}{ Kepatuhan Kemoterapi } & \multirow{3}{*}{ Jumlah } & \multirow{3}{*}{$\%$} \\
\hline & \multicolumn{2}{|c|}{ Patuh } & \multicolumn{2}{|c|}{$\begin{array}{c}\text { Tidak } \\
\text { Patuh } \\
\end{array}$} & & \\
\hline & $\mathbf{N}$ & $\%$ & $\mathbf{N}$ & $\%$ & & \\
\hline Baik & 99 & 82.5 & 2 & 1.6 & 101 & 84.1 \\
\hline Cukup & 6 & 5.0 & 6 & 5.0 & 12 & 10.0 \\
\hline Kurang & 3 & 2.5 & 4 & 3.4 & 7 & 5.9 \\
\hline Jumlah & 108 & 95.8 & 5 & 4.2 & 120 & 100 \\
\hline
\end{tabular}

Pasien kanker payudara yang mendapat dukungan keluarga kategori baik dan melakukan kemoterapi dengan patuh sebanyak $(82.5 \%)$. Untuk pasien dengan dukungan keluarga cukup dan melakukan kemoterapi dengan patuh sebesar (5.0\%). Sedangkan untuk pasien yang kurang mendapat dukungan keluarga namun melakukan kemoterapi dengan patuh sebanyak (2.5\%).

Adapun pasien yang mendapat dukungan keluarga dengan baik tapi tidak patuh dalam melakukan program kemoterapi sebanyak (1.6\%). Pasien yang cukup mendapat dukungan keluarga tetapi tidak patuh sebanyak (5.0\%). Dan bagi pasien yang kurang mendapat dukungan dari keluarga sedangkan tidak patuh dalam melakukan program kemoterapi sebesar $(3.4 \%)$. 
Hasil uji korelasi dengan menggunakan uji kendall-tau didapatkan nilai koefisien korelasi 0.607. Nilai signifikasi untuk mengetahui hubungan berarti atau tidak pada penelitian ini adalah 0.000 kurang dari nilai kemaknaannya yaitu 0.05 maka hal ini menunjukan adanya hubungan yang signifikan antara dukungan keluarga dengan kepatuhan pasien dalam menjalani kemoterapi.

\section{Dukungan Keluarga}

Berdasarkan tabel 2. dapat dilihat pasien yang memiliki dukungan keluarga baik sebanyak 101 orang (84.2\%), dukungan keluarga cukup sebanyak 12 orang (10.0\%), dukungan keluarga kurang sebanyak 7 orang $(5.8 \%)$. Sehingga tingkat dukungan keluarga yang diperoleh dari pasien kanker payudara yang menjalani kemoterapi di RSUD Abdul Moeloek termasuk dalam kategori baik.

\section{Kepatuhan}

Berdasarkan Tabel 2. didapatkan pasien yang patuh terhadap kemoterapi sebanyak 108 orang $(90.0 \%)$, sedangkan yang tidak patuh terhadap kemoterapi sebanyak 12 orang (10.0\%). Sehingga dapat dikatakan kepatuhan pasien dalam kategori baik. Kepatuhan sering disebut sebagai "complience dan adherence". Complience dan Adherence mengacu pada tingkat pasien melaksanakan tingkah laku dan pengobatan yang disarankan oleh dokter.

Kepatuhan menjalani kemoterapi adalah pasien dapat mengikuti pengobatan dari awal sampai akhir dengan mematuhi segala instruksi yang diberikan selama menjalani pengobatan (Patel dkk.,2013). Pada penelitian ini menunjukkan sebanyak 108 orang pasien (90\%) patuh terhadap pengobatan kemoterapi yang dijalankan. Hal ini tidak sesuai dengan penelitian yang dilakukan Souza dkk., (2012) yang menyatakan, Durasi dari pengobatan kemoterapi menyebabkan kepatuhan rendah karena mengikuti pengobaatan secara teratur sangat sulit (Souza dkk., 2012).

Selain dukungan keluarga hal lain yang dapat menjadi faktor yang mempengaruhi kepatuhan adalah tingkat ekonomi. Responden dalam penelitian ini kebanyakan memiliki tingkat ekonomi rendah, dimana dapat juga mempengaruhi kepatuhan. Terdapat pasien yang telah memiliki dukungan keluarga yang baik dan cukup, namun pasien tidak patuh menjalani kemoterapi. Setelah dilakukan wawancara terhadap pasien, pasien mengatakan hal yang membuat 
tidak menjalani kemoterapi tepat waktu adalah tidak adanya dana untuk akomodasi ke RSUDAM. Dikarenakan kebanyakan pasien yang tinggal di luar daerah kota Bandar Lampung.

\section{Simpulan dan Saran}

Berdasarkan hasil analisa data hubungan antara dukungan keluarga dengan kepatuhan psien kanker payudara menjalani kemoterapi di RSUD Dr. H. Abdul Moeloek Provinsi Lampung diperoleh kesimpulan sebagai berikut:

1. Seluruh responden berjenis kelamin perempuan yaitu sebanyak 120 orang $(100 \%)$.

2. Sebagian besar responden berusia $>40$ tahun yaitu sebanyak 94 orang $(78.3 \%)$.

3. Sebanyak 42 responden (35\%) berpendidikan SD.

4. Sebagian besar responden tidak bekerja yaitu sebanyak 84 orang $(70 \%)$.

5. Jenis kombinasi terapi terbanyak yang digunakan yaitu kombinasi CAF yaitu sejumlah 98 responden (81.7\%).

6. Sebagian besar pasien kanker payudara yang menjalani kemoterapi mendapatkan dukungan keluarga yang baik yaitu sebanyak 101 orang $(84.2 \%)$.

7. Sebagian besar pasien memiliki kepatuhan yang baik untuk menjalani kemoterapi yang sesuai sebanyak 108 orang (90.0\%).

8. Terdapat hubungan yang bermakna antara dukungan keluarga dengan kepatuhan pasien kanker payudara menjalani kemoterapi dengan nilai koefisien korelasi 0.607 dan nilai signifikansi 0.000. Dimana nilai koefisien bertanda positif yang artinya jika nilai dukungan keluarga tinggi maka nilai kepatuhan juga tinggi, demikian sebaliknya jika nilai dukungan keluarga rendah maka nilai kepatuhan juga rendah.

Berdasarkan kesimpulan yang disampaikan, peneliti juga memberikan saranyaitu:

1. Bagi Rumah Sakit diharapkan agar dapat memberikan konseling kepada keluarga pasien yang akan menjalani kemoterapi tentang pentingnya dukungan keluarga dalam mempengaruhi kepatuhan pasien dalam menjalani kemoterapi.

2. Diharapkan juga untuk membangun crisis center bagi pasien dan keluarga pasien.

3. Selain konseling dapat juga disediakan media seperti pamflet ataupun poster tentang pentingnya kepatuhan dalam menjalani 
kemoterapi dan faktor apa saja yang mempengaruhi kepatuhan tersebut.

4. Bagi keluarga dan pasien yang menjalani kemoterapi diharapkan penelitian ini dapat dijadikan informasi terutama bagi keluarga pasien bahwa kepatuhan pasien dalam menjalani pengobatan dapat dipengaruhi dukungan yang didapat dari keluarga.

\section{Referensi}

Aslam, M.S., Naveed, S., Ahmed, A., et al., (2014). Side effects of chemotherapy in cancer patients and evaluation of patients opinion about starvation based differential chemotherapy. Journal of Cancer Therapy, 5(8), p.817.

Ayurini, R.I., (2015). Kepatuhan pengobatan pada pasien kanker. (Doctoral dissertation). Program Studi Psikologi Unika Soegijapranata, Surakarta.

Bray, F., Ferlay, J., Soerjomataram, I., et al., (2018). Global cancer statistics 2018: GLOBOCAN estimates of incidence and mortality worldwide for 36 cancers in 185 countries. A cancer journal for clinicians, 68(6), pp.394-424.

Brody, J.G., Rudel, R.A., Michels, K.B., et al., (2007). environmental pollutants, diet, physical activity, body size, and breast cancer: where do we stand in research to identify opportunities for prevention?. Interdisciplinary International Journal of the American Cancer Society, 109, pp.2627-2634.

Kemenkes, R.I. (2013). Pusat data dan informasi kementerian kesehatan RI.

Lee, H.B., \& Han, W. (2014). Unique features of young age breast cancer and its management. Journal of breast cancer, 17(4), pp.301-307.

Notoatmodjo, S. (2010). Metodologi penelitian kesehatan.

Patel, K., Foster, N.R., Farrell, A., et al., (2013). Oral cancer chemotherapy adherence and adherence assessment tools: A report from north central cancer group trial n0747 and a 
systematic review of the literature. Journal of Cancer Education, 28(4), pp.770-776.

RI, K., (2015). Panduan penatalaksanaan kanker payudara. Acuan Pedoman Prakt Klin Kanker Payudara, pp.1-2.

Souza, B.F.D., Pires, F.H., Dewulf, N.D.L.S., et al., (2013). Patients on chemotherapy: Depression and adherence to treatment. Revista da Escola de Enfermagem da USP, 47(1), pp.61-68.

Wahyuni, A.T., \& Sarwinanti, S., (2016). Hubungan dukungan keluarga dengan kepatuhan mengikuti kemoterapi pada pasien kanker serviks di rsud dr. moewardi Surakarta. (Doctoral Dissertation). Universitas' Aisyiyah Yogyakarta, Yogyakarta. 